\title{
PANDEMICS AND DEVELOPMENT OF THE WORLD ECONOMY: A HYPOTHESIS OF CORRELATION
}

\author{
Le Chen ${ }^{1}$
}

Received: December 21, 2020 / Revised: February 1, 2021 / Accepted: April 2, 2021

(C) Association of Economists and Managers of the Balkans, 2021

\begin{abstract}
Coronavirus disease 2019-nCoV is a novel and highly transmissible infectious disease. However, in the history of human development, there have already been many infectious diseases that caused pandemics. Through a review of pandemics over centuries, the author tried to understand whether there was any correlation between the pandemics and the development of the world economy of the associated period. Although 2019-nCoV pandemic is deeply affected every country varying only in the degree, and the response measures taken by countries against the pandemic are also various, however, the pandemic has spread globally without exception; therefore, this study aims to call on to adopt a prevention strategy to face the new challenges ahead with a healthy rhythm of progressive globalization.
\end{abstract}

Keywords: Pandemic, Development, Environment, Correlation, Prevention.

JEL Classification F63 $\cdot$ I15 $\cdot$ O11

$\triangle \quad$ chenlemilan@gmail.com

$1 \quad$ University for Foreigners “Dante Alighieri”, Via del Torrione 95, Reggio Calabria, Italy 


\section{INTRODUCTION}

Historically, economic development at amazingly fast speed has enormously contributed to human development while has also sacrificed the environment, especially the development of the modern economy and the rapid rise of economic globalization has exacerbated environmental problems. The earth we depend on for survival is suffering from unprecedented disasters, and the destruction of the earth's natural ecology will eventually threaten the basic survival and development of human beings. In a sense, the $2019-\mathrm{nCoV}$ pandemic once again coincides with history. As a reflection upon the current situation caused by $2019-\mathrm{nCoV}$, it is natural to think back about the previous pandemics.

\section{OBJECTIVES AND RESEARCH METHODOLOGY}

Nothing has killed more human beings than infectious disease, despite today being a technology-led, innovation-driven globalization stage is no exception. Helpless we may feel in the case of coexistence with infectious disease, but we are far from powerless in this campaign. Therefore, this study attempts to learn from history for making a research proposal of a hypothesis on the potential correlation between the pandemics and the development of the world economy of the associated period. The aspects of research questions are as follows: hypothesis based on a review of six pandemics; rethinking the inevitability of the pandemics; what prevention should be taken to reduce the public safety risks triggered by a pandemic.

In this paper, the research proposal of a hypothesis is based on a review method with analysis of correlation to study the relationship between the pandemics and the development of the world economy of the associated period.

\section{HYPOTHESIS BASED ON A REVIEW OF SIX PANDEMICS}

As a first step towards the hypothesis, found in the previous research on a review of six pandemics is illustrated in the following table.

Table 1. A review of six pandemics

\begin{tabular}{|c|c|c|c|c|c|c|c|c|c|}
\hline \multirow[b]{2}{*}{$\mathrm{Nr}$} & \multirow{2}{*}{$\begin{array}{l}\text { Name of } \\
\text { Pandemic }\end{array}$} & \multirow{2}{*}{$\begin{array}{l}\text { Virus } \\
\text { Subtype }\end{array}$} & \multirow{2}{*}{$\begin{array}{c}\text { First } \\
\text { in }\end{array}$} & \multirow[b]{2}{*}{ Year } & \multirow{2}{*}{$\begin{array}{l}\text { Historical Back- } \\
\text { ground } \rightarrow \text { Economy }\end{array}$} & \multicolumn{4}{|c|}{ Estimated GDP ${ }^{1}$ (US\$, trillion) } \\
\hline & & & & & & Min & Max & $\begin{array}{c}\text { Span of } \\
\text { Years }\end{array}$ & Mean \\
\hline 1 & Russian Flu & $\mathrm{H} 3 \mathrm{~N} 8$ & RU & $1889-1890$ & $\begin{array}{l}\text { Modern industrial } \\
\text { age } \rightarrow \text { New transport } \\
\text { links, British banking } \\
\text { crisis in } 1890 \text { and the } \\
\text { world economy was in } \\
\text { recession }\end{array}$ & 1.1014 & 2.7048 & 44 & 1.8484 \\
\hline 2 & Spanish Flu & $\mathrm{H} 1 \mathrm{~N} 1$ & ES & $1918-1920$ & $\begin{array}{l}\text { World War } \mathrm{I}^{2} \rightarrow \\
\text { Cramped conditions of } \\
\text { soldiers and poor war- } \\
\text { time nutrition }\end{array}$ & 2.7048 & 5.3361 & 38 & 3.1664 \\
\hline
\end{tabular}

$2 \quad$ GDP is the final value of the goods and services produced within the geographic boundaries of a country during a specified period, normally a year.

Available at: http://www.ggdc.net/maddison/oriindex.htm, https://data.worldbank.org/indicator/NY.GDP.MKTP. CD https://www.imf.org/external/datamapper/NGDPD@WEO/OEMDC/ADVEC/WEOWORLD 
Balkan JETSS (2021) 1: 1-8

\begin{tabular}{|c|l|l|l|l|l|l|l|l|l|}
\hline 3 & Asian Flu & H2N2 & CN & 1957-1958 & $\begin{array}{l}\text { Vietnam War } \rightarrow \text { The } \\
\text { first world economic } \\
\text { crisis after World } \\
\text { War II }\end{array}$ & 5.3361 & 16.0592 & 24 & 9.1339 \\
\hline 4 & $\begin{array}{l}\text { Hong Kong } \\
\text { Flu }\end{array}$ & H3N2 & HK & $1968-1969$ & $\begin{array}{l}\text { Vietnam War } \rightarrow \text { An- } \\
\text { other economic crisis } \\
\text { since the Great De- } \\
\text { pression }\end{array}$ & 2.451 & 2.705 & 2 & 2.578 \\
\hline 5 & Swine Flu & H1N1 & MX & $2009-2010$ & $\begin{array}{l}\text { The world economy } \\
\text { has shown negative } \\
\text { growth for the first } \\
\text { time since World } \\
\text { War II }\end{array}$ & 60.396 & 66.113 & 2 & 63.2545 \\
\hline 6 & COVID-19 & $\begin{array}{l}2019- \\
\text { nCoV }\end{array}$ & CN & $\begin{array}{l}2019-2020 \\
\text { Oct }\end{array}$ & $\begin{array}{l}\text { The world economy } \\
\text { continues to be slug- } \\
\text { gish, and issues such } \\
\text { as trade frictions, geo- } \\
\text { graphic conflicts, and } \\
\text { financial market tur- } \\
\text { moil frequently arise }\end{array}$ & 87.698 & 83.84 & 1.833 & 85.5936 \\
\hline
\end{tabular}

Source: Based on Eprints.ugd.edu.mk, Worldbank.org, Ggdc.net

Cato stated in his book, "I am equally sure that the source of the current environmental stress - the evidence for which accumulates daily - is in economic activity" (Cato, 2020, p. 3). Environmental indicators are essential tools for tracking environmental progress. Since the early 1990s, such indicators have gained importance in many countries and international fora, and OECD countries increasingly use a reduced number of indicators, so-called "key indicators", selected from larger sets to report on major environmental issues. So far, there has not been a single indicator for measuring the world's environment.

As we all know that economic development has overwhelmed the air which represents one of the most crucial factors both for the ecological environment and for being influenced by the development of the world economy. Moreover, experts believe the virus that causes Coronavirus disease 2019-nCoV spreads mainly from person to person through the air. The air quality reflects the degree of air pollution. Especially, the development of the modern economy has made air quality a topic of increasing concern.

Air pollution can be measured by air quality indicators. They stated, "AQI (air quality index) is a numerical index based on measured concentrations of selected ambient air pollutants. It reports the severity of air pollution to the public and policy makers and specifies its adverse effects on human health. The AQI has been globally utilized to define the level of urban air pollution to protect human health and environmental resources". (Jassim and Coskuner, 2017, p.19). The following table lists more details.

Table 2. AQI and Interpretations

\begin{tabular}{|l|l|l|l|l|}
\hline $\begin{array}{l}\text { Air Pollu- } \\
\text { tion Level }\end{array}$ & AQI & $\begin{array}{l}\text { Mean AQI - } \\
>\text { World AQI }\end{array}$ & Air Quality Scale & Main Interpretation \\
\hline L1 & $0-50$ & 25 & Good & Air quality is considered satisfactory \\
\hline L2 & $51-100$ & 75.5 & Moderate & Air quality is acceptable \\
\hline
\end{tabular}

3 The data "about 125,000 tons of chemical agent were employed during World War I, and about 96,000 tons during the Viet-Nam conflict." is available at: Robinson, J. P. (2013). The Effects of Weapons on Ecosystems: Unep Studies (Vol. 1). Elsevier.

$4 \quad$ The Vietnam War (1955-1975) had significant environmental implications due to chemical agents which were used to destroy militarily significant vegetation. 


\begin{tabular}{|l|l|l|l|l|}
\hline L3 & $101-150$ & 125.5 & $\begin{array}{l}\text { Unhealthy for } \\
\text { sensitive groups }\end{array}$ & $\begin{array}{l}\text { Members of sensitive groups may experience health } \\
\text { effects }\end{array}$ \\
\hline L4 & $150-200$ & 175.5 & Unhealthy & Everyone may begin to experience health effects \\
\hline L5 & $201-300$ & 250.5 & Very Unhealthy & Health warning of emergency conditions \\
\hline L6 & $300-500$ & 400.5 & Hazardous & Everyone may experience more serious health effects \\
\hline
\end{tabular}

Source: Based on Waqi.info, 2020

As is known to all that the total amount and level of a country's economic development is based on the gross domestic product (GDP). Therefore, we use the total world GDP at the time of the pandemic. At the same time, let us obtain the support of this data from the AQI as a medium because we believe that in the past few centuries before this indicator came out, the impact of air quality on human health is no less important than today, and air quality is gradually deteriorating with economic development. Therefore, we subjectively assume the average value of AQI as the world $\mathrm{AQI}$ at that time and assign this value to the gradually developing world economy.

a. We have used Pearson Correlation Coefficient (Pearson's r) analysis to complete the calculation. In this paper, it is developed directly by the formula and graph embedded in excel. We assume world AQI as the variable Y and Estimated Mean GDP as the independent variable X. Where two values are derived from Table 1 and Table 2. We examine whether the dependent variable $\mathrm{Y}$ has a significant relationship with the independent variable $\mathrm{X}$, that is, Value $r$. The calculation based on Pearson's $r$ is given as follows:

$$
r=\rho_{X, Y}=\frac{\operatorname{Cov}(X, Y)}{\sigma X \sigma Y}
$$

A detailed logic is shown in the following table:

Table 3. Correlation calculation

\begin{tabular}{|l|r|r|r|r|r|r|}
\hline Nr Pandemic & 1 & 2 & 3 & 4 & 5 & 6 \\
\hline Independent Variable X & 1.8484 & 3.1664 & 9.1339 & 2.578 & 63.2545 & 85.5936 \\
\hline Dependent Variable Y & 25 & 75.5 & 125.5 & 175.5 & 250.5 & 400.5 \\
\hline Pearson's r & $0.917 \approx 0.9$ & & & & & \\
\hline
\end{tabular}

Source: Author's own calculation

b. Figure 1 shows scatterplots simulated with a correlation coefficient. As illustrated, $\mathrm{R}^{2}=\mathrm{r}=$ $0.8628 \approx 0.9$ indicates that there is linear relationship between the variables. Generally, second the interpretation of the correlation coefficient is 0.9 which indicates a close relationship ${ }^{5}$.

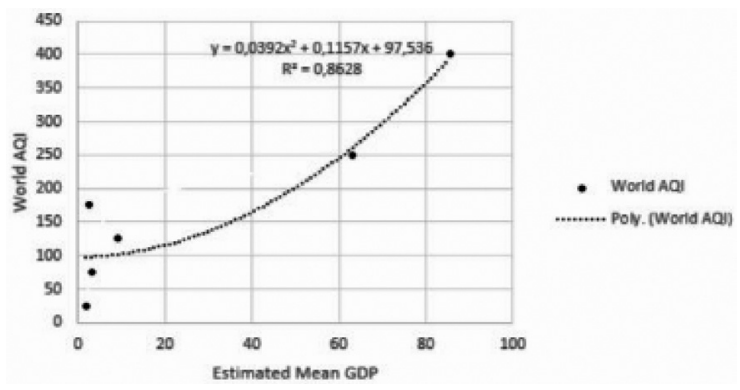

Figure 1. Correlation coefficient between Estimated Mean GDP and World AQI Source: Author's own calculation

\footnotetext{
$5 \quad$ Available at: Schober, P., Boer, C., \& Schwarte, L. A. (2018). Correlation coefficients: appropriate use and interpretation. Anesthesia \& Analgesia, 126(5), 1763-1768.
} 


\section{RETHINKING THE INEVITABILITY OF THE PANDEMICS}

Potter (2001) found "From the history of influenza epidemics and pandemics, which can be traced back with some accuracy for the past three hundred years, and with less certainty before this time... pandemics, occurring at 10 to 50 years' intervals, are due to new virus subtypes resulting from virus reassortment. Nothing has been introduced during the past 100 years to affect the recurrent pattern of epidemics and pandemics" (p. 572). The author even believes that the occurrence of pandemics correlates with the development of the world economy of the associated period. a. First, the existence of the virus has its own meaning. According to Domingo and Perales (2007), "Viruses probably had an ancient origin and have survived as agents of gene transfer and promoters of cell variation" (p. 1). It means that in the entire evolutionary process of our humans, viruses have played a particularly important role. Although the number and types have changed, they will never disappear. This point is also reiterated by Van Blerkom (2003) "Viruses may also have affected human evolution as agents of the genetic change via recombination and gene conversion. With their close association with cellular DNA, viruses have been in a position to directly affect the genomes of their hosts" (p. 37).

b. Secondly, there has never been a lack of a host that provides a living environment for viruses. Both the natural environment and the human beings, animals, and plants as part of nature are the natural hosts of viruses. They stated, "Viruses are extremely diverse and ubiquitous in nature. They evolve in continuous interaction with their host cells and organisms, following the general Darwinian principles: genetic variation, competition among variant forms and selection of the most fit variants in a given environment" (Domingo and Perales, 2007, p. 1). In the 20th century, after the First World War, the environment was greatly destroyed, non-limited to ecological imbalances, excessive production and consumption, weakness public health safety, etc. And in the 21st century, the destructive economic development models provided the most powerful breeding base for the breeding and reproduction of viruses. What is more important is that these do not contribute to the development of a healthy economy. They stated, "Today, the field of climate change and human health has expanded enormously, but still policymakers and the general public do not have a full understanding of its significance" (Weiss and McMichael, 2004, p. 18).

c. There are many types of viruses in nature, and they occasionally cross populations and spread to people or other animals. This is the virus ,spillover” that virologists worry about (Olival, 2017, p. 646), especially as shown in the figure Guangdong Province, which has had SARS and SADS outbreaks, which is specially circled with a red color. Also, we can see other 3 provinces as Yunnan, Guizhou, Hubei (starting place of 2019-nCoV) in which the degree of diversity and clustering of species distribution is relatively high. Other pandemics in Table 1 also have a similar feature. Van Blerkom found (2003), "Most animal viruses (about 70\%; Domingo et al., 2008) carry their genomes in the form of RNA...The capacity for RNA viruses to evolve extremely rapidly under some circumstances..." (p. 22), and "Coronaviruses, a common cause of colds in humans and enteric and respiratory infections in a variety of animals..." (p. 24). Besides, one of the big driving forces of infectious disease is also closely related to human activities. Human activities are expanding on a global scale, not only globalization but also including deforestation, agricultural intensification, wildlife trade, etc., which leads to the significantly increased frequency between animals and humans. All has triggered the possibility of new diseases appearing and spreading exponentially, and pandemics may become more frequent and more devastating in the future. 


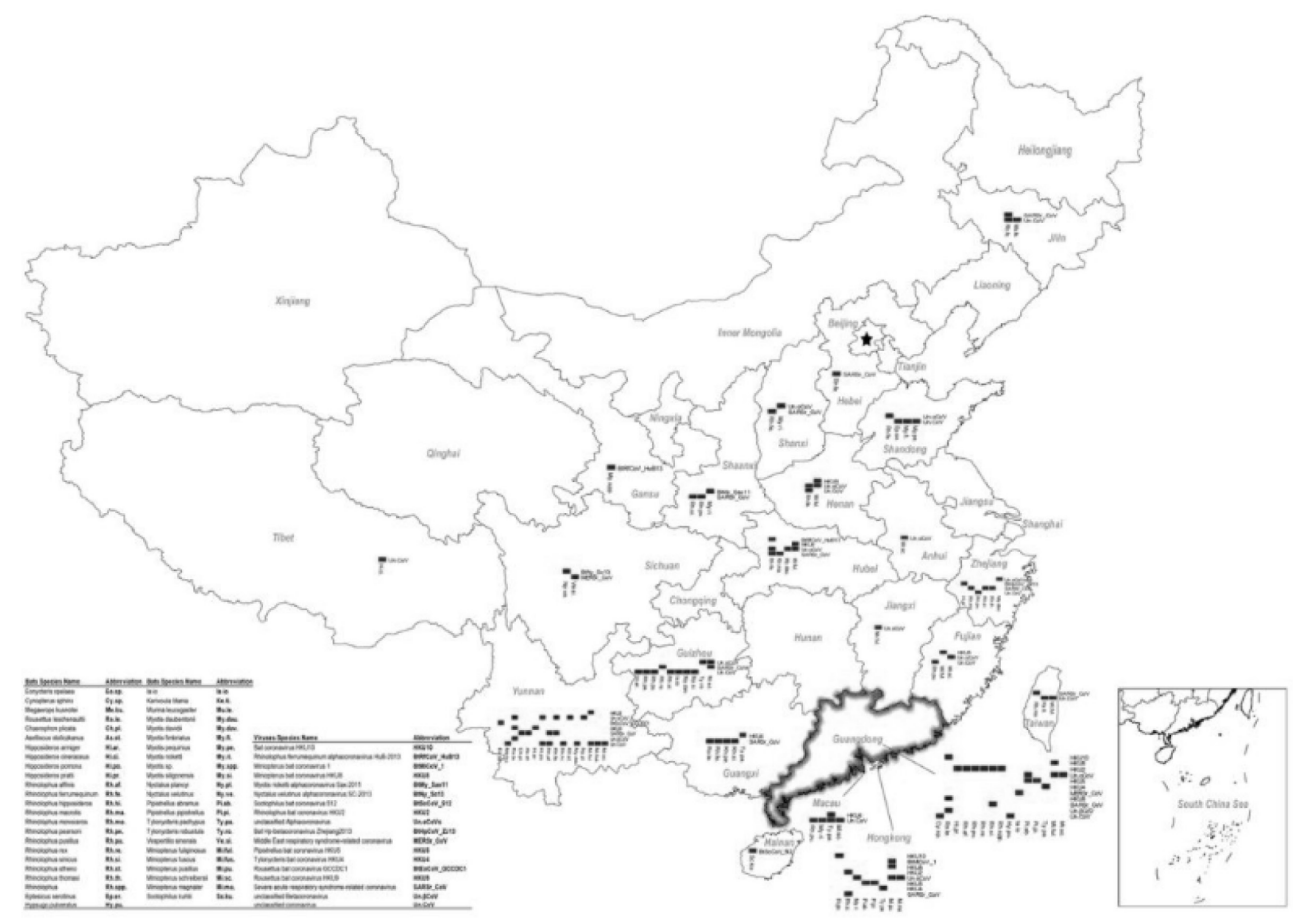

Figure 2. Distribution of bat coronavirus in China

Source: Reprinted from Fan, Y., Zhao, K., Shi, Z. L., \& Zhou, P. (2019). Bat coronaviruses in China. Viruses, 11(3), 210. (C) 2019 by the authors. Reprinted with permission of Creative Commons Attribution License.

\section{PREVENTION THAT SHOULD BE TAKEN TO REDUCE THE PUBLIC SAFETY RISKS TRIGGERED BY A PANDEMIC}

a. Professor Stiglitz, Joseph E in the latest book he has pointed out that "Globalization's impact goes far beyond economics" (Stiglitz, 2019, p. 98). With the great increase in productivity, the world's production capacity is hastily enhanced, and the standard of living is also rapidly improved. At the same time, it has also destroyed and polluted the surrounding environment, caused a series of environmental problems, such as severely over-exploited scarce resources, environmental degradation, ecological imbalance, species extinction, frequent calamities. We must learn from history and adjust today's economic model, and gradually globalize. If we have recognized some potential direct or indirect risks, we should change our behavior orientation, because prevention is far more economical, more effective, and more rational than remedy.

b. The "Double Smart" Prevention Strategy (including aspects of politics, institutions, economy, science, society, etc.) is developed in the context of 2019-nCoV pandemic. It is built based on a developmental perspective of the future of globalization aiming to provide a set of logics to improve public safety globally as the following (table 4). 
Table 4. "Double SMART” Prevention Strategy

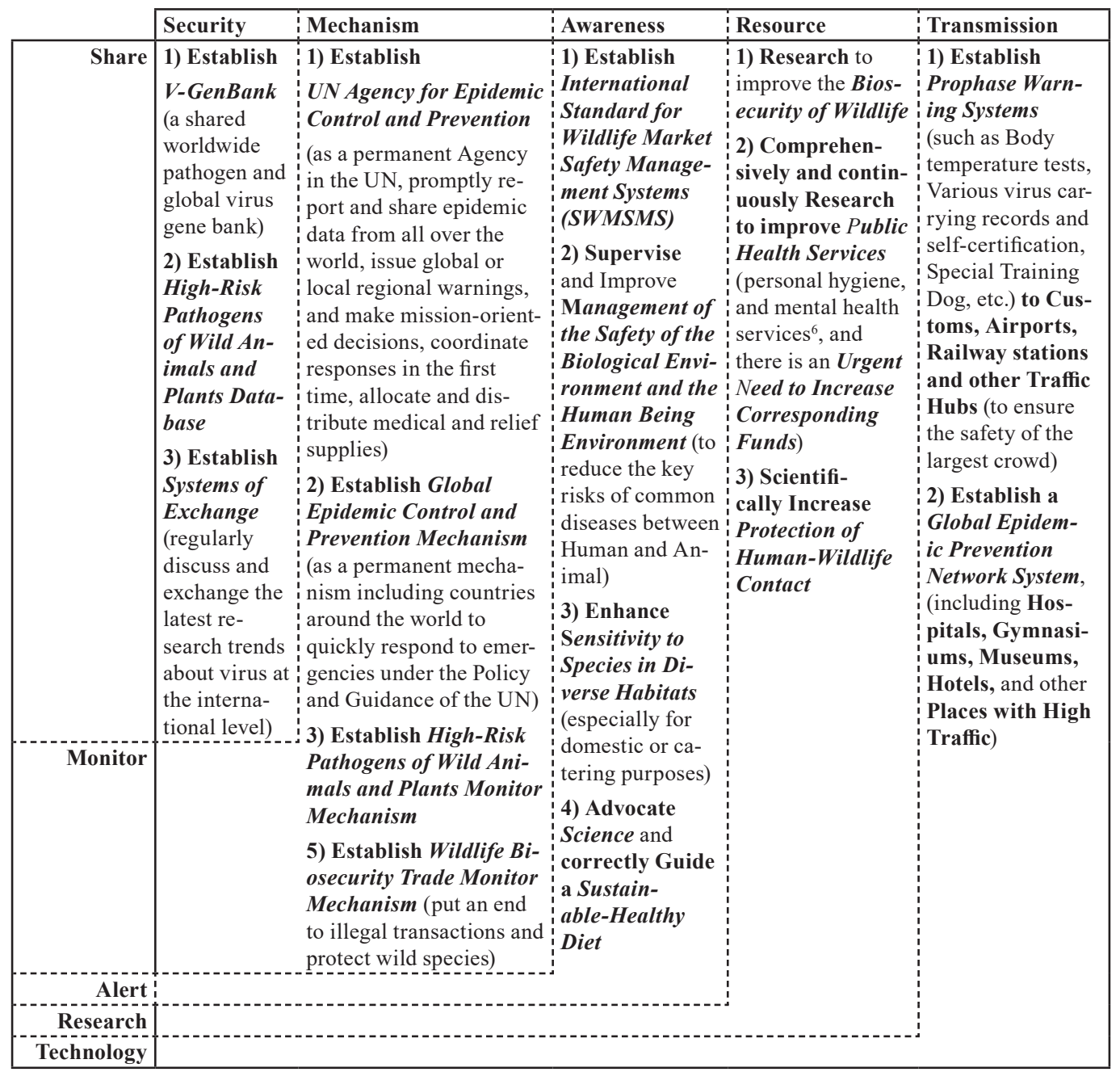

Source: Author's own elaboration

\section{RESULTS}

In the study, the author reports a correlation coefficient of 0.9 for the relationship between the pandemics and the development of the world economy of the associated period. Although the correlation is not equal to causality, proposal research between them showed the necessity of thinking about the important enlightenment they give us from the perspective of sustainable development.

That is to say, we should not only calculate the huge benefits that economic development brings to the development of human society, but also calculate the enormous costs of environmental changes for the survival and development of humans and other organisms in the future.

\footnotetext{
$6 \quad$ COVID-19 disrupting mental health services in most countries, WHO survey.

Available at: https://www.who.int/news/item/05-10-2020-covid-19-disrupting-mental-health-services-in-mostcountries-who-survey
} 


\section{FUTURE RESEARCH DIRECTIONS}

The present study, therefore, aimed at launching a research proposal, but more research is still needed to validate it. It has its limitations such as regards air as the primary measure of the quality of each period's environment, and high level of the subjectivity of assumptions on historical AQI values, and the very limited historical GDP data during the first three pandemics. Hereby, further studies should be performed to elucidate the potential correlation between the pandemics and the development of the world economy of the associated period.

\section{CONCLUSION}

Overall, economic and environmental development are in a dialectical and unified relationship. Their relationship is ultimately the relationship between humans and nature. How to handle their relationship and realize the benign interaction between the two is a life-or-death issue facing all mankind. We hope that this paper will have the objective effect of arousing the profound introspection of the whole society at the important moment for globalization, and we hope that it will help to further elaborate our proposed framework on this topic in order to achieve prevention-oriented international cooperation.

\section{REFERENCES}

Cato, M. S. (2020). Environment and economy. London, UK: Routledge.

Domingo, E., \& Perales, C. (2007). Virus evolution. eLS. https://doi.org/10.1002/9780470015902. a0000436.pub3

Domingo, E., Parrish, C. R., \& Holland, J. J. (Eds.). (2008). Origin and evolution of viruses. Elsevier.

Fan, Y., Zhao, K., Shi, Z. L., \& Zhou, P. (2019). Bat coronaviruses in China. Viruses, 11(3), 210. https://doi.org/10.3390/v11030210

Jassim, M. S., \& Coskuner, G. (2017). Assessment of spatial variations of particulate matter (PM 10 and PM 2.5) in Bahrain identified by air quality index (AQI). Arabian Journal of Geosciences, 10(1), 19. https://doi.org/10.1007/s12517-016-2808-9

Olival, K. J., Hosseini, P. R., Zambrana-Torrelio, C., Ross, N., Bogich, T. L., \& Daszak, P. (2017). Host and viral traits predict zoonotic spillover from mammals. Nature, 546(7660), 646-650.https:// doi.org/10.1038/nature22975

Potter, C. W. (2001). A history of influenza. Journal of applied microbiology, 91(4), 572-579. https://doi. $\operatorname{org} / 10.1046 / \mathrm{j} .1365-2672.2001 .01492 . x$

Stiglitz, J. (2019). People, power, and profits: Progressive capitalism for an age of discontent. London, UK: Penguin.

Van Blerkom, L. M. (2003). Role of viruses in human evolution. American Journal of Physical Anthropology: The Official Publication of the American Association of Physical Anthropologists, 122(S37), 14-46. https://doi.org/10.1002/ajpa.10384

Weiss, R. A., \& McMichael, A. J. (2004, in Press). Social and environmental risk factors in the emergence of infectious diseases. Nature medicine, 10(12), S70-S76.

\section{ADDITONAL READING}

Markovski, V., Zdravkovska, M., Taleski, V., Shishkova, D., \& Debreslioska, A. (2014). Epidemiološki karakteristiki na gripot vo R. Makedonija. In: 5-th Congress of Macedonian Microbiologists with International Participation, May 28-31, 2014, Ohrid, Macedonia.

McMichael, A. J. (2000). The urban environment and health in a world of increasing globalization: issues for developing countries. Bulletin of the World Health Organization, 78, 1117-1126. 